\title{
The Anfortas question
}

Previously published at www.cmaj.ca

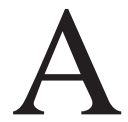
s part of the efforts by hospital administration to remain within budget, a suggestion was made at a Canadian hospital to omit the dictation of admission histories and physicals and, instead, to cut and paste relevant sections from previous admission notes using the electronic patient record. This suggestion made me think about the hours I spent as a medical student and resident taking bedside histories. Why should we now bother taking a history beyond the presenting complaint at all, if, in the age of the electronic patient record, all we have to do is click 'copy' for the rest? Is the skill of taking a complete, diagnostically helpful history outdated, and should we stop teaching it to the future generations of medical students?

One way to answer these questions is to contemplate one of the earliest descriptions of a medical history - or, to be more precise, the description of not taking a history. The essence of history-taking, I think, lies in the act of a caring human being - a doctor, a nurse, anybody - directing an inquiry at a suffering human being, the patient.

Wolfram of Eschenbach's epic poem, written in the first quarter of the 13th century, depicts the travels and trials of the medieval legend of the knight Parzival. ${ }^{1}$ As a young man, Parzival was kept hidden from the outside world in a forest by his wellmeaning mother. As a result, he is very naive when he finally sets out on his own, but learns some rules of conduct from an old master whom he meets. His travels lead him to the castle where the Holy Grail is kept - the Grail in this particular legend depicted as a physical object: a mystical vessel. He is shown a bloody spear while at the same time the keeper of the Grail, Anfortas, is carried into the room.

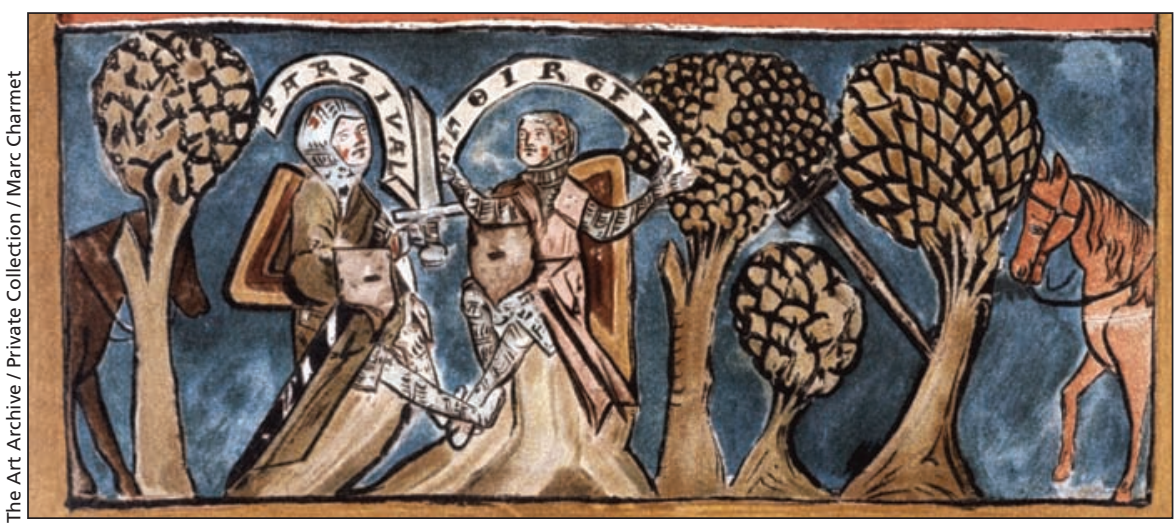

Anfortas has a chronic wound and is obviously suffering from it, but Parzival, although extremely curious about what he sees, keeps silent as he has been taught it is not polite to speak first. The next morning he finds the castle nearly deserted and as he leaves he is nearly struck by the drawbridge slamming shut behind him - a reflection of his perceived hardheartedness.

After many years, during which Parzival suffers wounds and trials himself and achieves knighthood, he again comes to the castle of the Grail. The same scenario plays out, but this time, Parzival asks: "Uncle, what is it that troubles you?" Immediately, Anfortas' wound heals and amid jubilation Parzival is named as the new Keeper of the Grail.

One can only speculate about the way in which Parzival must have asked the question "What is it that troubles you?" in order for it to have had such a therapeutic effect. I think it must have been asked not just to gather information or to help him understand the situation, but also because he felt compassion toward the suffering patient. A fundamental way to express compassion is to enquire about the inner state of the other. And it was that component of Parzival's brief, but effective history that had a therapeutic effect.

I believe that 800 years after this legend was written down, its lesson holds true: History-taking can be therapeutic if done with compassion. It may not heal physical wounds, but it may ease the emotional scars suffered during illness. It doesn't matter that Parzival did not receive an answer to his question. What matters is the question. Every time a patient says "Thanks for asking!" or "Thank you for taking the time to listen!" - even though we may have no idea what to do for them or what the diagnosis may be - we can be assured that somewhere, somehow we must have posed the Anfortas question. We have connected. Let us continue to teach this skill to the Parzivals of today and tomorrow as we send them, computers in hand, to see patients and ask the same old question in innumerable different variations and situations: "How are you?"

\section{Michael Susmoy Sanatani MD}

Assistant Professor of Oncology

University of Western Ontario.

London, Ont.

\section{REFERENCE}

1. Von Eschenbach W. Translated by Hatto AT Parzival. Toronto (ON): Penguin Classics; 1980.

Do you have an opinion about this article? Post your views at www.cmaj.ca. Potential Salon contributors are welcome to send a query to salon@ cmaj.ca. 